\title{
Fish Value Chain and Its Impact on Rural Households' Income: Lessons Learned from Northern Ethiopia
}

\author{
Abebe Ejigu Alemu ${ }^{1}$ and Hossein Azadi ${ }^{2,3,4, *(1)}$ \\ 1 College of Business and Economics, Department of Management, Mekelle University, P.O.Box 231 Mekelle, \\ Ethiopia; abebe.ejigu@mu.edu.et \\ 2 Department of Geography, Ghent University, 9000 Ghent, Belgium \\ 3 Department of Engineering Management, University of Antwerp, 2000 Antwerp, Belgium \\ 4 Research Group Climate Change and Security, Institute of Geography, University of Hamburg, \\ 21073 Hamburg, Germany \\ * Correspondence: hossein.azadi@ugent.be; Tel.: +32-09-264-4695; Fax: +32-09-264-4985
}

Received: 12 August 2018; Accepted: 10 October 2018; Published: 18 October 2018

check for updates

\begin{abstract}
These days, one of the global challenges is the growing demand for food. To be more specific, seafood bases play a key role in filling the nutritional requirements of human beings. In Africa (Ethiopia) the public expenses to improve productive capacity in aquatic food are increasing. Additionally, the expenses in dams and in fishers' capacity building have increased households' engagement in the fishery sector in Ethiopia. Cooperatives' productive capacity has been strengthened by the government and other non-government organizations with the supply of fishing boats, refrigerators, fish nets and other office supplies. However, the effect of such public expenses in bringing changes in the households' livelihood and welfare has never been assessed in this study area. This paper aims to investigate what motivates the households to fish and assess the effect of fisheries on the households' livelihood and welfare. A structured survey consisting of 313 rural households was administered using trained enumerators in two kebeles located close to the Tekeze dam, Northern Ethiopia. The result indicates that socioeconomic characteristics, such as age (young), sex, education, and active family size were driving the households to fishing. Access to market and access to support are driving farmers to fisheries. There is a significant difference in fishing households' income which is higher than non-fishing households. The results also indicate that there are lesser income inequalities among fishery households operating in cooperatives compared to private fishery households.
\end{abstract}

Keywords: cooperative; food security; food supply; fishery; value chain; livelihood and welfare; Ethiopia

\section{Introduction}

There is a major priority to maintain food security at the national and household level for most developing countries in terms of both well-being and vulnerable groups [1]. Despite ongoing efforts to provide a more stable, sustainable and predictable food supply, there is a considerable population in the developing world that still suffer from chronic under-nutrition. In the developing world, there are a large number of populations who are farmers and are considered as a main source for labor employment [1]. Smallholder farmers and family farming dominate the agricultural system, and four out of every five households are involved in farming [2]. Similarly, Sub-Saharan Africa has more agricultural applications. Additionally, in a consensus among African leaders (in Mozambique and Maputo) it was indicted that agriculture was considered as a sector to reduce poverty and they agreed to increase spending on agriculture up to $10 \%$ of the national budget. Hence, many countries in Africa 
continue to increase spending on agriculture but only eight countries including Ethiopia reached $10 \%$ by 2008 [3].

The government aims to improve households' productive capacity through the expansion of extension services, supply of agricultural technology and inputs. There are ongoing supplies of technology and inputs for various agricultural sectors such as crop production, livestock, apiculture and fishery which led to increased yield in these sub-sectors.

The growing global population can be an opportunity in spending on agriculture. However, it is a challenge for technical experts, governments and researchers on how to feed this growing population [4]. Spending in agriculture is also rational due to the growing food shortage, the rural poverty situation and the increase in young labor force. These days, one of the global challenges is the raising demand for food. To be more specific, seafood bases play a key role in filling the nutritional requirements of human beings. Spending on fisheries capacity building is an area of rural development as it plays a fundamental role in creating employment opportunities, providing dietary preferences for the middle income consumer group, and meeting nutritional needs of the poor regions [5]. Fisheries are one of the important and renewable natural resource bases for many developing countries, and the livelihood of many rural communities relies on the fishery sector [6]. In the developing world, about 116 million people are benefited from the fishery sector and about $90 \%$ of them are working in the small-scale fisheries sector [7]. Accordingly, fisheries is a key sector for reducing poverty and it could be considered as a potential strategy because it helps to diversify household income directly and indirectly [8]. Projections also indicate that the aggregation of global fish supply will increase to 186 million tons (year 2030) compared to the 154 million tons (year 2011) [5].

For developing countries, fish is becoming one of the leading export commodities in terms of providing national income [9]. Despite the leading role of the fishery sector in diversifying income source and meeting nutritional requirements, fishery communities in the developing world are generally poor $[6,8,10]$. The main reasons could be reduction in fish resource bases, due to open access fisheries or poorly managed fishing operations, and low access to alternative income $[8,11,12]$.

In addition, lack of sufficient demand, hygiene and lack of cool chains to transport products to market challenged the development of the fishery sector in Northern Ethiopia. In the survey conducted in Mekelle in 2011, nearly 6\% of the respondents' consumed fish in six months, implying that the poor fish consumption trend in the region is impeding the enhancement of the fishery sector. However, in Ethiopia, evidence suggests that meat consumption goes back to 3.39 million years ago [13], yet the current level of animal protein consumption is considerably lower than the global average. Although Ethiopia is known for its large livestock population, there is a limited contribution of livestock to household diets. In Ethiopia the average annual per capita of diary consumption and meat products are 22.4 liters [14] and $4.6 \mathrm{~kg}$, respectively [15].

Ethiopia is known as the water tower of Eastern Africa, which provides about $86 \%$ of the Nile water (i.e., the sum of Blue Nile (59\%), Sobat/Baro-Akobo (14\%), and Tekeze (13\%)) [16] for rural and semi-urban households, mainly the unemployed. These rivers and other water resources of the country are considered as huge potential sources of fish and employment opportunities. The big fresh water artificial lakes are the result of construction of mega hydroelectric dams in Ethiopia (i.e., Tekeze hydroelectric). These lakes have improved the fish production potential in the country $[17,18]$.

The dam has created fishing opportunities for two cooperatives and households providing an alternative income source for member households and individual's livelihoods. The cooperatives host 204 households and help generate income by selling fish to retailers, restaurants, hotels and consumers in Mekelle and other cities in the country. It has also helped households to get employed. Nevertheless, fishers raise the issues of demand problems and other constraints affecting their engagement in the sector. There has been huge public spending and endeavor in building the dam and enhancing the capacity of cooperatives with boats, fish nets and training. However, the contribution of fisheries to household livelihoods has not been adequately assessed. The constraints fishers face in supplying fish to market, and the linkages of fishery cooperatives to the market are not sufficiently addressed. 
This paper aims to identify the determinants that drive households to fisheries and assess the impact of fishing on household livelihood and welfare which is measured in terms of household income. The paper employs a value chain framework to rural livelihood diversification and poverty reduction as it is an emerging dimension to rural development [19].

\section{Value Chain Approach for Livelihood Diversification and Poverty Reduction}

Rural households are under income pressure as their source is mainly from crop production. Diversifying their livelihood, by combining crop production with off-farm and non-farm activities, is an important strategy for the rural livelihoods in developing countries [20]. Livelihood diversification is a survival strategy among the rural households; i.e., more diversified livelihood implies less vulnerability and more secured households [21,22]. Upgrading value chains diversifies livelihood strategies by creating opportunities for added products, processes, functions, and channels. Analyzing value chains helps to evaluate actors, processes, roles, the way actors share benefit, and the relationships and linkages among actors [23].

The value chain analysis is an approach to enhance value added activities that would enable smallholders to diversify income sources and reduce poverty [19]. Value chain analysis is one of the basic dimensions in identifying activities, actors, relationships, constraints, and possible upgrading of production and marketing activities to add values and create opportunities for new actors (the poor) or new values/economic benefits for producers (smallholders) and actors in the value chain [19,24].

There are different value chain analysis approaches investigating the linkages and relationship between different actors and economic agents (individuals, companies, government) in the value chains. For example, value chain finance approach can make an important contribution, though for a limited range of crops and farmers, and it is largely focused on credit. There are additional (though important) instances beyond what general financial services can offer. These services include new delivery channels, products, or business models, which may be needed to address the specific risks and cash flows of agriculture. As an example for this approach, Borbora (2014) [25] aimed to find out the critical points in value chain practice existing in rural farm and nonfarm sectors in North Eastern Region of India. He tried to find out a possible solution so that these value chains can be linked to financial service providers for the betterment of the rural mass.

To represent another example, small-scale fisheries feed into diverse and spatially extensive networks of supply and trade that connect production with consumers, adding significant value and generating important levels of employment (the value chain). As an example for assessing small-scale fisheries, Rosales et al. (2017) [26] examined eight value chain studies, carried out for specific fish species in different locations around the Philippines. They also discussed policy and management lessons learned and interventions resulting from the value chain analysis for small-scale fisheries management.

A value chain perspective of the small-scale fisheries sector can reveal response strategies that enhance the sustainability and competitiveness of the entire value chain and the economic agents that comprise it. Value chain analysis helps to effectively isolate the binding constraints that affect the sector in a systematic manner [27]. The set of issues that emerge from such a detailed analysis at a sector level has implications for both the public and private sectors alike. Some of the issues are sector-specific, and others are relevant across an economy and apply to many sectors and firms in a country. It also provides an opportunity to find policy and management positions that can be supported by the sector's different economic agents and important stakeholders [27].

Value chain analysis involves analyzing processes (activities), identifying actors and their roles in the added value and identifying the position of the smallholder (the poor). Moreover, it analyzes the value distribution across actors, the degree of relationship/integration and governance among actors and identifies constraints of producers and other actors.

As an example for the mentioned features of value chain analysis, Andriesse (2018) [28] conducted an analysis of four important products affecting at least 3 million households in the Philippines. This study showed that the integration of livelihoods and value chain analyses has the 
advantage of modifying upstream challenges that are both relevant for agri/aquabusiness performance, socioeconomic, and socio-spatial policies.

To be more specific, the value chain approach enables researchers and practitioners to view activities/processes performed to add value to products and the actors involved in the chain. It also helps to identify constraints and opportunities for further upgrading the value chain to include (more) actors/smallholders in the chain [23]. It is also used to analyze the degree of relationships among the actors and the coordination mechanism within the value chain $[27,29]$. The approach is also useful for identifying the missing links and activities in the chain and to suggest intervention areas to upgrade the chain so as to include actors (the poor) in the value system. Value chain approach is praised for creating rural employment opportunities where unemployment is widespread [30].

The African economy is largely agrarian, and its population produces and consumes products with minor processing. Farmers also offer products to the market with insignificant value added, activities that, in turn, result in less value and minimal return to farmers. The absence of integrated value chains makes producers retain products at home, which, in turn, reduces farmers' motivation to improve productivity and market participation. Poorly organized value chains also hamper farmers' commitment to investment in transforming agriculture and transition to agro-processing which escalates rural unemployment in various regions of the continent [30].

To be more specific, a large number of farmers in Ethiopia are smallholders who have no adequate market access or bargaining power, and are liable to accept prices and terms specified by the traders [31]. The participation of the private sector in agro-processing is also small, inhibiting farmers from investing in agriculture and reducing their motivation to raise their productivity. These aggravate the poverty situation in the country and push smallholders to sustain in subsistence agriculture. The recent study on fish consumption in Mekelle (the state capital) revealed that not more than $6 \%$ of the sample households had consumed fish in the preceding three months [14]. Availability, knowledge on product, and cultural reasons were raised by consumers. However, more than $70 \%$ showed interest in consuming fish which signals the presence of sufficient potential demand for fish.

There is no rigorous study that has been conducted with regard to the role of value chain approach in development programs. The value chain approach is considered relevant for this study as it focuses on the value chain and its effect on livelihood diversification and poverty reduction. The study assesses the livelihood contribution of fish to rural households' income [21]. In addition, it will assess the constraints that fishing households face; such as the problems of cooperatives in marketing fish while there is sufficient actual and potential demand for fish in the country.

The current literature largely focuses on transaction costs and market structure in relation to farmer-buyer transactions instead of understanding the value chain from input supply to consumption. Current literature dwells less on the impact of demand side requirement such as consumer preferences as the impediments to farmers' productivity and market participation. Hence, the value chain approach is a systemic approach, which assesses actors and constraints and enables us to identify opportunities for upstream and downstream chain actors.

Therefore, the value chain approach is recommended for mapping the value chain, identifying drivers for farmers to engage in fishing, examining constraints affecting cooperatives in supplying fish, assessing the impact of fishing on household livelihood and welfare, investigating constraints in the chain and providing possibilities for improving the capacity. Additionally, this approach improves the linkages of the fishers with various market actors, which may also increase market power benefiting from fishery operation. If there is an increase in income, they will invest in technology and enhance production and improve the sustainability of the operation. Hence, the approach will facilitate the transformation of traditional fishery operations and upgrade the sector to high value chains. Upgrading the sector will lead to the inclusion of more households or unemployed youth in the sector, the improvement of livelihood, and the reduction in rural poverty. 


\section{Methodology}

\subsection{Research Site and the Sample}

The Tekeze River is formed by the river flowing through one of the deepest canyons in the world by the construction of the hydropower dam [18]. The river flows from the central highlands of Ethiopia close to the mount Qachen of Lasta [18]. The dam location is $155 \mathrm{kms}$ from Mekelle, the capital of Tigray, Northern Ethiopia (Figure 1). Two Tabias (the smallest administrative unit) (Seye and Felegehiwot) are direct beneficiaries of the dam and sample households were chosen for the survey. The two Tabias contained individual and cooperative fishery households. The rural household survey composed of non-fishery and fishery households was administered using trained enumerators. Trained enumerators under our supervision were assigned to administer the questionnaires. In addition, the data from the two cooperatives were collected so as to understand their capacity, members, challenges and prospects.

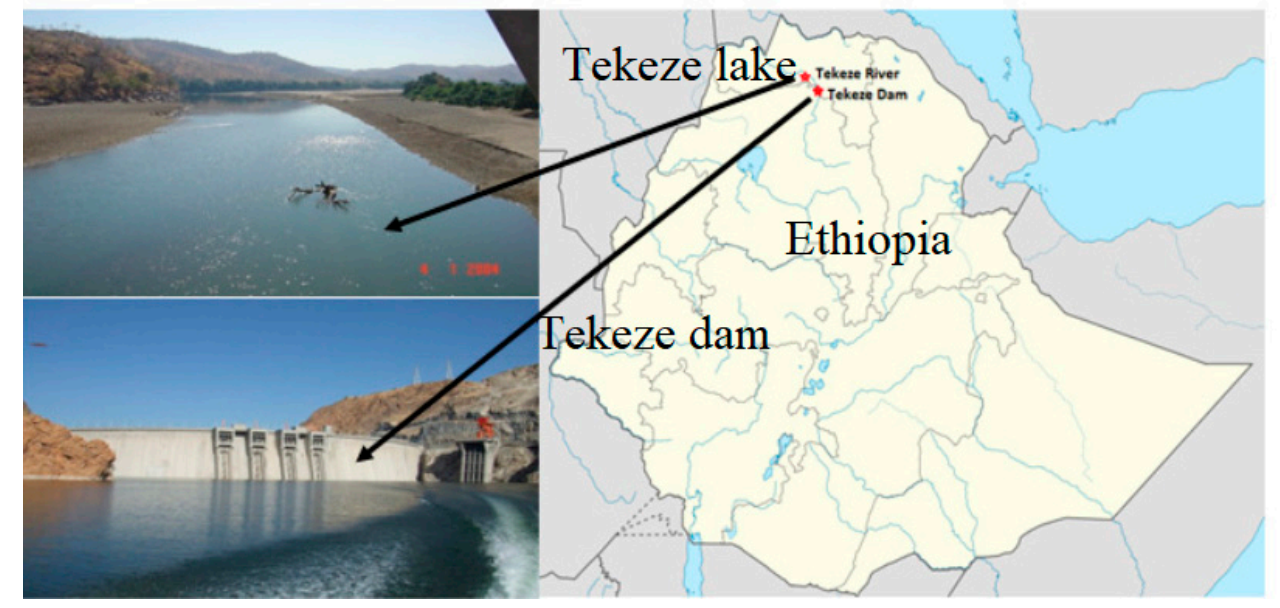

Figure 1. The dam at the Tekeze River (adapted from Desta et al. [18]).

In order to apply the propensity score to the matching model, a list of questions was developed for the fishing and non-fishing households as follows:

(a) Type of education of the household head, (b) How many household members participate in the fishery? (c) Village distance from rivers/lakes or reservoir/dam, (d) Whether they have access to an irrigation system? (e) How much money did they earn in the last month from selling fish?

In order to measure the added-value activities, actors, costs at different stages and the analyses of the value distribution, different questions were developed for hotels and cooperatives as follows:

(a) What is their educational background? (b) What is their function in the fish value chain? (c) How long have they been in fish collection and trading? (d) How do they rate the fish quality supplied to them? (e) What kinds of fish do their clients like the most? (f) How do they see their relationship with the fishery cooperative?

During data collection, about 1430 households in the two Tabias and 313 households were selected as the sampled respondents using following sampling formula by Yamane (1967) cited in Israel (1992) [32]:

$$
\mathrm{n}=\frac{\mathrm{N}}{1+\mathrm{N}(\mathrm{e})^{2}}
$$

where, $\mathrm{n}$ = sample size, $\mathrm{N}=$ population size, $\mathrm{e}=$ (error margin). The sample size was drawn on the 1430 population with $95 \%$ confidence level and error margin of 5\% is 313. Of which, 62 members from the two cooperatives and 246 non-member households (of whom 52 were found fishing individually) were determined to be respondents for the questionnaire distributed. The list of households was obtained from the Rural Development Office (RDO) of the Tabias and random sampling was used to select the responding households. 


\subsection{Empirical Model for Analyzing the Contribution of Fisheries to Household Income}

To assess the effect of fishery in the rural household's livelihood, livelihood differences between fishery and non-fishery households was considered and the impact analysis model was employed. These models include propensity score matching techniques and regression on observables. If regression on observables is applied, then there may be a selection bias because participation in fishing is not random. In order to correct the potential bias which might be occurred due to the non-random selection into fishing, a large set of observable covariates were included as control variables using the following equation:

$$
\mathrm{Y}_{\mathrm{i}}=\alpha+\gamma \mathrm{F}_{\mathrm{i}}+\beta \mathrm{X}_{\mathrm{i}}+\varepsilon_{\mathrm{i}}
$$

where $Y_{i}$ is the household income (in birr (1 USA dollar = 27.96Ethiopian Birr in Oct. 2018)), and F shows the participation in fishing. To correct the potential bias, the vector $X$ includes a large set of observable covariates: Distance to RDO, distance to market, land size, number of oxen, active family size, education, sex and age. Additionally, Ordinary Least Squares (OLS) was used for the estimation.

In the regression model, the second estimation model is according to the predicted propensity scores (or a conditional probability to engage in fishing) implemented as additional control variables. The potential bias created by selection on observable characteristics will be decreased by the propensity score [33]. The mentioned model is described as follows:

$$
\mathrm{Y}_{\mathrm{i}}=\alpha+\gamma \mathrm{F}_{\mathrm{i}}+\mu \mathrm{PS}_{\mathrm{i}}+\beta \mathrm{X}_{\mathrm{i}}+\varepsilon_{\mathrm{i}}
$$

with $\mathrm{PS}_{\mathrm{i}}=\mathrm{p}(\mathrm{F}=1 / \mathrm{X})$; where PS refers to Propensity Score.

Third, Propensity Score Matching technique (PSM) will estimate the effect of fishing on the households. This technique involves matching on propensity scores. In the agricultural and development economics literature this method is widely applied in the impact assessment [14,34-36]. The model is considered as the best option in solving selection bias when randomization and experimental design is difficult [37]. The households, who are similar in terms of observable characteristics were treated by PSM matches $[33,38]$. When the set of potentially relevant characteristics is large; it is a difficult task to match observable characteristics directly. Matching on propensity scores is known as a valid method to solve this problem [39].

In the sample, all fishing households (the treated observations) will be matched with one or several non-fishing households (control observation). These samples have similar propensity scores (as described in Equation (3)). The impact of fishing on household income can then be estimated as a weighted difference in income (between treated observations and matched controls) using the following equation:

$$
\mathrm{ATE}=\mathrm{E}\left(\mathrm{Y}_{1}-\mathrm{Y}_{0}\right)=\frac{1}{\mathrm{~N}} \sum_{\mathrm{i} \in \mathrm{N}}\left(\mathrm{Y}_{1 \mathrm{i}}-\mathrm{Y}_{0}\right)
$$

where the Average Treatment Effect (ATE) is representing the average treatment effects of fishing activities, $\mathrm{N}$ shows the number of households participating in fishing, $\mathrm{Y}_{1}$ represents the fishing households' outcome and $Y_{0}$ is the control group's outcome for the (non-fishing households).

PSM is created based on two basic assumptions: Conditional Independence (CI) and Common Support (CS). CI represents potential outcomes, which is independent of treatment assignment considering a set of observable covariates X [39-41]:

$$
\mathrm{Y}_{0}, \mathrm{Y}_{1} \perp \mathrm{F} \mid \mathrm{X}
$$

The second assumption refers to the presence of adequate overlap in the distribution of the propensity scores (both treated and control observations) [39,40]:

$$
0<\mathrm{P}(\mathrm{C}=1 \mid \mathrm{X})<1
$$


The analysis of the quantitative data and the implementation of the model is conducted using STATA 11 statistics software.

\section{Results and Discussion}

\subsection{The Fish Value Chain}

To analyze and map the fish value chain, cooperatives and individual fishers and respective buyers were considered (Figure 2). More specifically, the fish value chain is composed of suppliers of technology and input such as the government and non-government organizations, the fisheries (cooperatives and individuals), processors and distributors (hotels, restaurants, retailers) and consumers. The rural households participate in cooperative or individual fishing as fisher, processor, seller and user (consumer). Rural households gain economy benefits from fish sales and employment and feed households contributing to household food security/nutrition. The fishery subsector hence diversified sources of income for rural households in the two Tabias: They get dividends, income from sales, wage from employment and food supply for the household.

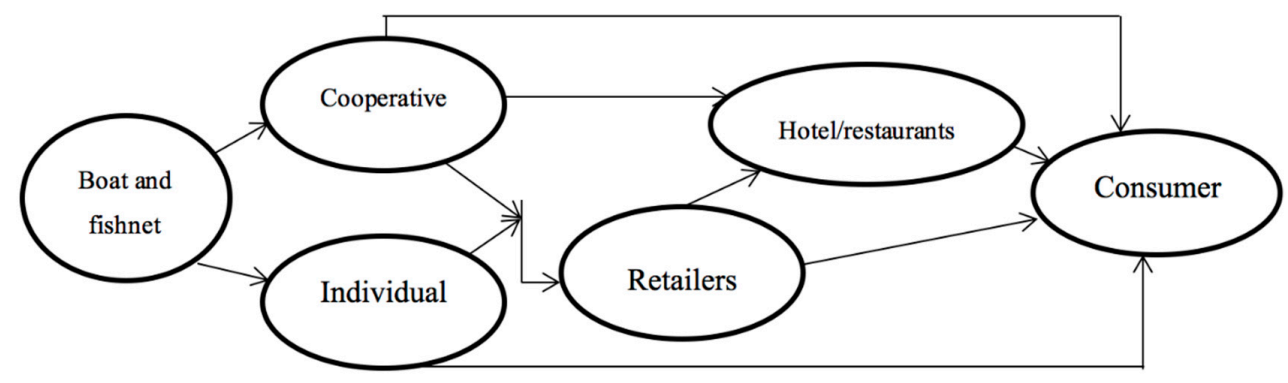

Figure 2. Fish value chain.

The regional Agriculture and Rural Development Bureau has attempted to develop the fishery sector to exploit the sector's potential. Two fishing cooperatives (Kisanet and Tekeze) are operating in the district. The Tekeze cooperative was established in 2010 and Kisanet was established in 2012 and both of them got support from the government and non-government organizations. The provided support included fishing boats, refrigerators, fishnets and other operating supplies. Tekeze hosted 126 members of which 61 were female and the rest 65 were male. Kisanet had 78 members of which 13 were female. The starting capital for Tekeze was Birr 20,000 which grew to Birr 4 million. The starting capital for Kisanet was Birr 48,300 which grew to 2.8 million. The sources of the capital were members, government support (Mekelle University), aid from the Relief Society of Tigray (REST) and credit.

The number of fishing boats for Tekeze and Kisanet were 80 and 33 respectively which enabled them to extract $600 \mathrm{~kg}$ and $700 \mathrm{~kg}$ of fish daily. Tekeze cooperative supplied on average $83 \%$ of the fish stock daily to market and the rest $17 \%$ to its own members. Kisanet cooperative on the other hand supplied $95 \%$ to the market and the rest to its members. The result reveals that all cooperative members consume fish. Activities in cooperatives include fishing, processing (removing fish bones), packing, distribution and selling fish and members participate in any of these activities. Tekeze and Kisanet cooperatives distributed Birr 48,000 and Birr 25,000 every month respectively as dividend to members. The cooperatives employed 210 temporary and permanent employees.

The cooperatives were supported with fishing boats, refrigerators, motor bicycles, and fish nets. The cooperatives are on the verges of creating employment opportunities, providing fish as food to the household and generating income to its members by selling fish to hotels and distributors. They supplied fish mainly to Mekelle which was also extended to Shire and Addis Ababa. Two basic coordination schemes were used: Transactional and relational. They directly sell fish in open markets and they also sell fish in contract (relational basis). On both cases, the selling price was Birr 30/kg. Cooperatives raise the insufficiency of relational markets (contracts) and contractors sometimes failed to buy the fish stock they made available to them. Cooperatives also raise the practice of unregulated 
fisheries and propose the implementation of policy to regulate fishing operations around the dam. The unregulated fishery may endanger the future of the fish stock and affect their livelihood.

There is also a general lack of qualified aquaculture marketing personnel. The inadequate personnel in the aquaculture front demands more training. New training institutions should be established and the existing institutions should be assisted with exchange programmes and logistics to undertake more work on value chain. The Ministry of Fisheries and Aquaculture Development through the Fisheries Commission have been sending some of their personnel to Iceland, UK, Korea and China for aquaculture training. Few workers of the Fisheries Commission occasionally upgrade themselves outside Ghana. There is urgent need to strengthen the capacity of personnel working on aquaculture farms.

Four actors in the fish value chain perform collecting and reselling. The added value by these four actors includes processing (removing bones and packing fish meat), storing and reselling. They acquired fish supply from cooperatives individuals and retailers (collectors). Statistically, $94 \%$ of the actors replied that they added the value including processing (removing bone; $82 \%$ ), packing $(47 \%)$, and cooking $(82 \%)$

The transaction relationship among the actors takes two basic forms. Eight of the actors (47\%) had agreements with suppliers (persistent relationships), whereas the rest (nine; 53\%) bought on the spot market on transactional bases. Actors largely supply fish to consumers; that is, 14 of the actors $(82.35 \%)$ supplied to consumers. Supply fluctuation was raised by $53 \%$ of the actors and the rest did not feel it. Demand variation, price changes and lack of cool chain were also mentioned by the actors as problems facing the chain. Absence of quality assuring and standardizing institution was also mentioned as a challenge, although kilogram was used as main units of measurement.

\subsection{Summary Statistics on Rural Households}

Differences in socioeconomic characteristics of fishing and non-fishing households are presented in Table 1 . The table depicts that $97 \%$ of the fishing households were male-headed and $87 \%$ of the non-fishing households were male-headed, and the difference is statistically significant at the $1 \%$ level. This implies that both fishing and non-fishing households are male dominated. Male domination however is higher in the fishing households implying the male biased fishery subsector. Female members of the fishing cooperative participate in processing and selling activities rather than fishing. This may call for implementing measures to attract female headed households in the subsector.

Table 1. Differences in socioeconomic characteristics.

\begin{tabular}{ccccc}
\hline \multirow{2}{*}{ Variable } & \multicolumn{2}{c}{ Fishing } & \multicolumn{2}{c}{ Non-Fishing } \\
\cline { 2 - 5 } & Mean & Std. Dev. & Mean & Std. Dev. \\
Sex & 0.97 & 0.16 & $0.87^{\mathrm{a}}$ & 0.34 \\
Age (years) & 34.26 & 9.75 & $37.80^{\mathrm{a}}$ & 12.14 \\
Education (years) & 3.08 & 1.45 & $2.42^{\mathrm{a}}$ & 1.61 \\
Household size & 5.74 & 2.17 & $5.34^{\mathrm{c}}$ & 2.13 \\
Active family member & 2.47 & 1.00 & $2.17^{\mathrm{a}}$ & 1.12 \\
Households attending school & 2.01 & 1.59 & 1.87 & 1.68 \\
Land size (ha) & 1.09 & 0.69 & 1.19 & 0.78 \\
Access to irrigation & 0.04 & 0.18 & 0.05 & 0.22 \\
Irrigated land size (ha) & 0.03 & 0.22 & $0.11^{\mathrm{b}}$ & 0.42 \\
Distance to market (km) & 34.10 & 35.59 & $12.43^{\mathrm{a}}$ & 15.06 \\
Village distance to Mekelle (km) & 149.11 & 8.48 & $146.03^{\mathrm{a}}$ & 8.39 \\
Village distance to Yechila district (km) & 37.41 & 14.46 & $44.02^{\mathrm{a}}$ & 14.91 \\
Village distance to dam (km) & 10.07 & 4.47 & 9.88 & 3.61 \\
Village distance to FTC (km) & 4.53 & 3.55 & 4.20 & 2.43 \\
Households consuming fish & 0.95 & 0.22 & $0.34^{\mathrm{a}}$ & 0.47 \\
\hline Number of observations & 114 & & 199 & \\
\hline a,b,c are levels of significance at $1 \%, 5 \%, 10 \%$ levels for & t-test. &
\end{tabular}

$a, b, c$ are levels of significance at $1 \%, 5 \%, 10 \%$ levels for $t$-test. 
Fishing household heads were relatively younger than the non-fishing household heads implying that the sub-sector is attracting the youth, contributing to the employment opportunity and engagement of the growing part of the rural community. This may be considered as an opportunity for the increasing young labor force in the rural areas who are largely landless.

The summary statistics show that fishing household heads were relatively better educated than the non-fishing household heads. This may imply that the more that household heads learn, the higher is the probability of households to engage in fishing. The difference in educational status is statistically significant at the $1 \%$ level. Once the dam was open for fishing, the communities surrounding the dam did not show interest to operate in fishing for which better educated household heads found it easy to join the sector and engage in fishing.

In terms of family size and active family members, fishing households had large family sizes and active family members which might push them to be involved in fishing. The simple t-test has proved the presence of significant differences in family size and active family between fishing and non-fishing households which are statistically significant at the $10 \%$ and $1 \%$ level respectively.

The size of the irrigated land also varies between the fishing and non-fishing households. Non-fishing households were found irrigating larger land size in contrast to the fishing households. This may imply that non-fishing households concentrate more in crop farming than other alternative income sources like fishing. This is statistically significant at the $5 \%$ level. This implies that in areas where land is scarce and access to irrigation is minimal, fishing is considered as an alternative income source used to diversify livelihood strategies.

Fishing households live farther away than non-fishing households from Mekelle. The ones who are closer may prefer non-farm activities (daily labor) in Mekelle instead of spending their time in fishing. Nevertheless, the fishing households are closer to the district town (Yechila) where the hotels are located. In this town, all government offices are situated including the Agricultural and Rural Development Office (ARDO) which offers integrated agricultural support. Both are statistically significant at the $1 \%$ level.

This analysis clearly indicates the importance of fish to the food security and nutritional needs of most fishing families. This finding is consistent with the study of Asiedu (2012) [42] in which despite the large fish potential, a few organized fisheries are operating attributed to lack or absence of fish consumption habit. In relation to fish consumption pattern, $95 \%$ of the fishing households consume fish at household level in contrast to the $34 \%$ non-fishing households, which is statistically significant at the $1 \%$ level. This implies how fish is contributing to the households' food security and nutritional requirements. Households consume, on average, 1.6 (approximately 2) days in a week. However, as Altenburg (2007) states [43], involving the rural poor in value chain development calls for a sound approach to address the complex trade-offs between income generation, food security, gender equity, sustainable natural resource management, and the overall livelihood resilience.

Differences in household income, agricultural and non-agricultural assets were also assessed as depicted in Table 2. It presents that non-fishing households possess more agricultural assets than the fishing households, which may imply the dependence of non-fishing households on crop farming. Credit taken by fishing households was larger compared with the non-fishing households, which may imply that access to credit has built their fishing capacity. The income from fishing has also given courage to take credits for fishing households. Fishing households are also characterized by higher income from fishing and working in cooperatives, attributing to higher total income by fishing households. Both of them are statistically significant at the $1 \%$ level, implying the significant contribution of fisheries to rural households. 
Table 2. Differences in income.

\begin{tabular}{ccccc}
\hline \multirow{2}{*}{ Variable } & \multicolumn{2}{c}{ Fishing } & \multicolumn{2}{c}{ Non-Fishing } \\
\cline { 2 - 5 } & Mean & Std. Dev. & Mean & Std. Dev. \\
\cline { 2 - 5 } Total agricultural asset value & 350.14 & 344.66 & $553.70^{\mathrm{c}}$ & 1350.57 \\
Total non-agricultural asset value & 1396.69 & 1960.86 & 1637.43 & 2481.97 \\
Total livestock value & $12,923.68$ & $22,279.17$ & $12,422.84$ & $10,321.06$ \\
Total livestock product value & 150.82 & 542.52 & 291.89 & 1108.02 \\
Wage income & 462.51 & 2230.43 & 651.78 & 1706.74 \\
Business income & 846.41 & 3012.48 & 2047.78 & $11,277.05$ \\
Food for work & 249.39 & 275.35 & 284.48 & 247.07 \\
Cash for work & 10.79 & 61.46 & $107.04^{\text {a }}$ & 208.17 \\
Natural resource income & 0.00 & 0.00 & 0.15 & 2.13 \\
Idir income & 66.01 & 657.02 & 30.10 & 291.75 \\
Credit taken & 5618.42 & $24,099.75$ & $2937.08^{\mathrm{c}}$ & 7831.43 \\
Income from fishery & 5461.99 & $16,351.95$ & $0.00^{\mathrm{a}}$ & 0.00 \\
from working in cooperative & 846.50 & $11,998.14$ & $0.00^{\text {a }}$ & 0.00 \\
Total household income & $12,560.42$ & $12,309.30$ & $74,77.50^{\text {a }}$ & $13,453.45$ \\
\hline no. of observations & 144 & & 199 & \\
\hline a,c are levels of significance at $1 \%, 10 \%$ levels for $t$-test. & &
\end{tabular}

The survey result reveals that fisheries constitute $36.61 \%$ and of which $20 \%$ were cooperative fisheries and the rest $(16.61 \%)$ were individual fisheries. Cooperative members contributed on average Birr 1202.42 and they obtained annual dividends which is worth, on average, Birr 4562.38. They also earned on average Birr 2822.58 annually from working in the cooperative. It is the source of food for the fishing households contributing to the household food security. All cooperative members consumed fish, on average, 13.56 (approx. 14) days in a month implying the contribution of fish to the rural households in the district.

Analysis on the differences in income and assets among non-fishing, cooperative fishery and individual fishery households is also presented in Table 3. The results indicate that fisheries have contributed to the increased income, regardless of the operation method. However, cooperative fishing results in better income in terms of fish sales and participating in employment in the cooperative, and is significant at the $5 \%$ level in contrast to the non-fishing households.

The results of fisheries constitute clearly indicate that many inland fishers are interested in the aquaculture business, but they need to be supported with other inputs such as seed, feed, credit facilities and veterinary services. Generally, most farms are not productive because of poor husbandry practices, feeding and pond management. The technical knowledge in these areas is very poor. Training institutions, agencies and developmental partners must collaborate with the government to provide training and extension services to fish farmers to improve their knowledge in aquaculture practices.

Table 3. Differences in income, asset and livestock.

\begin{tabular}{ccccccc}
\hline \multirow{2}{*}{ Variable } & \multicolumn{2}{c}{ Non-Fishing } & \multicolumn{2}{c}{ Individual Fisheries } & \multicolumn{2}{c}{ Cooperative Fisheries } \\
\cline { 2 - 7 } & Mean & Std. Dev. & Mean & Std. Dev. & Mean & Std. Dev. \\
\hline Total household income & 7477.24 & $13,453.45$ & $11,026.44^{\mathrm{c}}$ & $23,363.50$ & $11,122.06^{\mathrm{b}}$ & $10,658.04$ \\
total livestock asset value & $12,422.84$ & $10,321.06$ & $13,883.65$ & $31,359.83$ & $12,118.55$ & 9789.03 \\
total nonagricultural asset value & 1637.43 & 2481.97 & 1407.87 & 1711.26 & 1387.32 & 2161.97 \\
total agricultural asset value & 553.70 & 1350.57 & 375.87 & 294.26 & $328.56^{\mathrm{c}}$ & 382.91 \\
\hline Number of observations & 199 & 52 & 62 \\
\hline \multicolumn{7}{c}{ b,c are levels of significance at $5 \%, 10 \%$ levels for $t$-test. }
\end{tabular}

This finding is consistent with the study of Fowler and Brand (2011) [44] in which between the fishing households, no significant income difference is observed. However, while observing the standard deviation, fewer differences in income might be inferred among cooperative members which 
indicates lower inequality; whereas, huge income difference among individual fisheries is implying greater inequality among them. Nevertheless, the agricultural asset value for non-fishing households is higher in contrast to cooperative members, which may lead us to conclude that non-fishing households are largely involved in farming, and cooperative members are diversifying their livelihood strategies by engaging in fishing.

\subsection{Empirical Model Result}

\subsubsection{Determinants to Fishing}

Analyses on what drives households to fishing is also being done by employing binary logit model assuming that households' move to fishing is a discrete choice. Choosing to work in a fishery could be affected by different factors such as socioeconomic factors, access to market, access to support (FTC), asset possession (i.e., land) and oxen ownership. In rural Ethiopia, oxen ownership, access to off farm inputs and market credit are considered as the major factors for production and crop farming. The logit regression result reveals that sex, age, education, household size and active family were among the household characteristics affecting households' engagement in fishing. Male households are more driven to fishing and it is significant at the 10\% level. Young household heads are more driven to fishing and it is significant at the $1 \%$ level. Educated household heads are participating more in fishing than the less educated ones and it is significant at the $1 \%$ level. Larger family size is also driving households to fishery.

Distance to FTC, where extension support is channeled and access to any support from government and non-government organizations are found, is stimulating households to fishing. This implies that government spending for extension and technology has contributed to households' engagement in fishing. Besides, distance to district market is also driving households to fishing as it facilitates access to market and other market actors.

The farm asset ownership is negatively affecting engagement in fishing. The larger land size and oxen possession imply less participation in fisheries and more dependence on crop farming. These may push households to specialize and concentrate more on crop farming. Accordingly, the logit result reveals that households with larger land size and more oxen are found less driven to fishing which is significant at the $10 \%$ and $1 \%$ level, respectively.

There are adequate number of processors available, but the technology applied to processing is relatively low in terms of the level of investment and/or basically traditional (sun drying, small size smokers and salting). These low-technologies of processing turn to be labor intensive, but provide livelihood support to the fishers (women) especially those in the rural communities in Africa; however, it is difficult to sustain such jobs. As observed by De Silva and Yamao (2006) [45], female roles in fish processing (especially in processing factories) are associated with job insecurity, health issues and harassment. Consequently, there is the need for innovation in the processing sector in addition to women empowerment.

Table 4 reveals the marginal effect and indicates that by an increase in the number of male headed households, the propensity for fishing would be increased by $20 \%$ that is significant at the $1 \%$ level. By increasing one year in the age of the household head, the propensity to fishing reduces by $1 \%$. An increase in the year of education implies the increase in the likelihood of fishing by $4 \%$. An increase in the size of the family raises the propensity to fishing by $6 \%$ and an increase in active family implies the rise in the probability of fishing by $10 \%$. An increase in the distance to Yechila would reduce the probability of fishing by $1 \%$. A unit increase in the number of oxen reduces the probability of fishing by $9 \%$. If the amount of cash increases by 1000 Birr from cash for work, the probability of fishing would diminish by $9 \%$. If households' access to support (government and non-government support) increases, the probability of fishing increases by $31 \%$ (Table 5). 
Table 4. Determinants to participate in fishing.

\begin{tabular}{ccc}
\hline Variable & Coefficient & Robust Std. Err. \\
\hline Sex & $1.43^{\mathrm{c}}$ & 0.76 \\
Age & $-0.07^{\mathrm{a}}$ & 0.02 \\
Education & $0.21^{\mathrm{c}}$ & 0.11 \\
Household size & $0.31^{\mathrm{a}}$ & 0.09 \\
Active Family & $0.52^{\mathrm{a}}$ & 0.18 \\
Land size & $-0.46^{\mathrm{c}}$ & 0.24 \\
Access to irrigation & $1.00^{\mathrm{a}}$ & 0.73 \\
Distance to district market & $-0.06^{\mathrm{a}}$ & 0.02 \\
Distance to Dam & $0.00^{\mathrm{a}}$ & 0.08 \\
Distance to FTC & $0.23^{\mathrm{c}}$ & 0.13 \\
No. of oxen 5 years ago & $-0.46^{\mathrm{b}}$ & 0.18 \\
Off-farm access & $0.10^{\mathrm{a}}$ & 0.49 \\
Petty trade & -0.65 & 0.56 \\
Cash for work & $-0.01^{\mathrm{a}}$ & 0.00 \\
Credit & 0.00 & 0.00 \\
Access support & $1.46^{\mathrm{a}}$ & 0.48 \\
Constant & -1.41 & 1.63 \\
\hline Number of obs. & 309 & \\
Wald Chi2(15) & $68.76^{\mathrm{a}}$ & \\
Pseudo R & 0.259 & \\
\% correctly predicted & & $75.73 \%$ \\
\hline ab, are leve o & \\
\hline
\end{tabular}

$\mathrm{a}, \mathrm{b}, \mathrm{c}$ are levels of significance at $1 \%, 5 \%, 10 \%$ levels.

Table 5. Marginal effects.

\begin{tabular}{ccc}
\hline Variable & Coefficient & Robust Std. Err. \\
\hline Sex & $0.20^{\mathrm{a}}$ & 0.07 \\
Age & $-0.01^{\mathrm{a}}$ & 0.00 \\
Education & $0.04^{\mathrm{c}}$ & 0.02 \\
Household size & $0.06^{\mathrm{a}}$ & 0.02 \\
Active Family & $0.10^{\mathrm{a}}$ & 0.04 \\
Land size & $0.09^{\mathrm{c}}$ & 0.05 \\
Access to irrigation & 0.23 & 0.18 \\
Distance to district market & $-0.01^{\mathrm{a}}$ & 0.00 \\
Distance to Dam & $0.00^{\mathrm{a}}$ & 0.02 \\
Distance to FTC & $0.04^{\mathrm{c}}$ & 0.03 \\
No. of oxen 5 years ago & $-0.09^{\mathrm{b}}$ & 0.04 \\
Off-farm access & $0.02^{\mathrm{b}}$ & 0.10 \\
Petty trade & -0.11 & 0.09 \\
Cash for work ('000) & $0.09^{\mathrm{a}}$ & 0.00 \\
Credit & 0.00 & 0.00 \\
Access support & $0.31^{\mathrm{a}}$ & 0.10 \\
\hline a,b,c are levels of significance at $1 \%, 5 \%, 10 \%$ levels.
\end{tabular}

\subsubsection{Effect of Fishing on Household Livelihood (Income)}

The descriptive statistics have indicated the differences in income between fishing and non-fishing households. However, the descriptive statistics cannot explicitly indicate the attribution of fishing to such differences in income. The regression model and propensity score matching model was applied to assess the contribution of fish to household income difference. The results of the two models are presented in Table 6. 
Table 6. Effect of fishing on household income.

\begin{tabular}{ccccc}
\hline \multirow{2}{*}{ Outcome variable } & $\begin{array}{c}\text { OLS-Regression } \\
\text { Estimation }\end{array}$ & PS-Regression & \multicolumn{2}{c}{ Propensity Score Matching } \\
\cline { 2 - 4 } & $\begin{array}{c}\text { Coefficient } \\
\text { (Standard Error) }\end{array}$ & $\begin{array}{c}\text { Coefficient } \\
\text { (Standard Error) }\end{array}$ & $\begin{array}{c}\text { Coefficient } \\
\text { (Standard Error) }\end{array}$ & $\begin{array}{c}\text { Coefficient } \\
\text { (Standard Error) }\end{array}$ \\
\hline Household income $(\log )$ & 0.62 & 0.60 & 0.55 & 0.77 \\
$(0.30)^{\mathrm{b}}$ & $(0.32)^{\mathrm{c}}$ & $(0.33)^{\mathrm{c}}$ & $(0.46)^{\mathrm{c}}$ \\
\hline
\end{tabular}

Three models were applied to measure the effect of fishing on rural households and the model results reveal consistent and statistically significant positive effects of fishing on household income. If we take the most conservative result, participating in fishing has contributed to a $55 \%$ change in the incomes of households in contrast to the non-fishing households implying the positive contribution of fish to diversify rural livelihood strategies and reduce rural poverty.

In this regard, there is the need for documentation, database, information etc., on aquaculture and fishery products that should be recorded and available online for general public purposes. However, as Rosales et al. (2017) [26] states, a value chain analysis provides a different perspective on the fishery sector than a traditional socio-economic or resource and ecological assessment. The conduct of a value chain analysis involves an examination of how the individual actors operate, what is going on between the actors in the chain, what keeps the actors together, what information is shared, what power relationships exist, and how the relationships evolve. Due to the high incidence of the poor in the fisheries sector, the value chain framework can also be used to draw conclusions on the participation of the poor and the potential impact of value chain development on poverty reduction.

\section{Conclusions and Policy Recommendations}

Generally, a value chain analysis is conducted to identify improvements in quality and product design that enable producers to gain enhanced value or through diversification in the product lines. However, a range of data and information used to manage the fishery sector, not just markets, can also be produced. The Ethiopian population is largely agrarian which employs inadequate technology and inputs, leaving the people in persistent poverty. To improve the situation, government and non-government organizations have expanded the extension services and aimed to support building the productive capacity for the rural households. Ethiopian aquaculture is recognized as an alternative approach to maintain food security in particular and to reduce poverty in general. Currently the integration of Ethiopian aquaculture is considered as the leading strategy in rural and agricultural development. The Ethiopian government is largely spending on technology and the provision of credit and assets empowering households to participate in crop farming, livestock and fishing. The Tekeze dam built in Northern Ethiopia by the government, is open for famers to fishing, in addition to its objective of generating hydroelectric power. However, rural households were originally less interested in participating in fishing for the fear of the poor fish consumption culture. Nevertheless, cooperatives were established with some volunteer households by providing fishing boats, refrigerators and fish nets by the government. Nevertheless, the demand for fishing is growing from time to time attracting more rural households to engage in fishing.

Based on the gained results, it can be concluded that socioeconomic variables such as age (young household heads), sex, family size and active family members contribute to rural households' engagement in fishing. In addition, closer distance to markets and access to rural support stimulate households to engage in fishing. Nevertheless, households with larger land and large number of oxen are less stimulated to participate in fishing as they concentrate more on farming. Those households with less land and a lower number of oxen are moved to fishing as it enables them to diversify their income sources.

It was concluded that fishing has created employment opportunities for young labor force and large family size households. The fisheries produce substantial social benefits in the form of rents, 
producer surplus and consumer surplus. It has contributed to diversifying household livelihoods, generating more income to engaged households. The rural households' fish consumption has grown timely, implying the food security contribution of fish in the rural areas. Furthermore, the empirical analyses suggest that fishery has also increased the households' income improving the livelihood conditions of households calling for the governments and NGOs' extended support to attract more households to engage in the sector and scale up the strategy to other dams built in different corners of the country. In addition to building the productive capacity, linking fisheries to the market would also improve the income of the households as it minimizes fish waste. Improving fisher-actor coordination would also improve the productivity and enhancement of the chain to attract more actors (rural poor) in the sector. Given these findings, designing an effective policy to regulate water use would improve the sustainability of the sector and minimize conflicts among the fisheries surrounding the dam. Water use polices will minimize competition among the individual fisheries and cooperatives which may lead to overfishing and waste of resources and this will provide a great incentive to properly manage the fisheries. It is expected that value chain studies can further provide substantial bases for future interventions that will promote sustainable fisheries, ensuring the improvement of the livelihood conditions at the same time.

Author Contributions: A.E.A. performed the study and wrote the main text. H.A. provided instruction and comments for the research design, approach, and the paper.

Funding: This research received no external funding.

Conflicts of Interest: The authors declare no conflict of interest.

\section{References}

1. Carruth, R.A. Global Governance of Food and Agriculture Industries: Transatlantic Regulatory Harmonization and Multilateral Policy Cooperation for Food Safety; Edward Elgar: Cheltenham, UK, 2006. Available online: http:/ / www.nlb.gov.sg/biblio/12511085 (accessed on 4 October 2007).

2. Biénabe, E.; Boselie, D.; Collion, M.H. The Internationalization of Food Retailing: Opportunities and Threats for Small-Scale Producers. In Regoverning Markets: A Place for Small-Scale Producers in Modern Agrifood Chains? Vorley, B., Fearne, A., Ray, D., Eds.; Gower: Aldershot, UK, 2007; pp. 3-17.

3. Bewketu, W. Rainfall variability and crop production in Ethiopia case study in the Amhara region. In Proceedings of the 16th International Conference of Ethiopian Studies, Trondheim, Norway, 2-6 July 2007; pp. 823-836.

4. FAO. How to Feed the World in 2050. 2009. Available online: http://www.fao.org/fileadmin/templates/ wsfs/docs/expert_paper/How_to_Feed_the_World_in_2050.pdf. (accessed on 12 March 2014).

5. World Bank. Fish to 2030: Prospects for Fisheries and Aquaculture, The World Bank. 2013. Available online: http://www.fao.org/docrep/019/i3640e/i3640e.pdf (accessed on 1 December 2013).

6. Béné, C.; Friend, R.M. Poverty in small-scale fisheries: Old issue, new analysis. Prog. Dev. Stud. 2011, 2, 119-145. [CrossRef]

7. World Bank. The Hidden Harvests the Global Contribution of Capture Fisheries: Agriculture and Rural Development Department-Sustainable Development Network; The FAO and the World Fish Center: Washington, DC, USA, 2010.

8. Olale, E.; Henson, S. The impact of income diversification among fishing communities in Western Kenya. Food Policy 2013, 43, 90-99. [CrossRef]

9. Béné, C.; Lawton, R.; Allison, E.H. Trade Matters in the Fight Against Poverty: Narratives, Perceptions, and (Lack of) Evidence in the Case of Fish Trade in Africa. World Dev. 2010, 38, 933-954. [CrossRef]

10. Platteau, J.P. Penetration of Capitalism and Persistence of Small-scale Organizational Forms in Third World Fisheries. Dev. Chang. 1989, 20, 621-651. [CrossRef]

11. Driscoll, R.; Evans, A. Second-Generation Poverty Reduction Strategies: New Opportunities and Emerging Issues. Dev. Policy Rev. 2005, 23, 5-25. [CrossRef]

12. Starvins, R. The Problem of the Commons: Still Unsettled after 100 Years. Am. Econ. Rev. 2011, 101, 81-108. [CrossRef] 
13. McPherron, S.P.; Alemseged, Z.; Marean, C.W.; Wynn, J.G.; Reed, D.; Geraads, D.; Bobe, R.; Béarat, H.A. Evidence for stone-tool-assisted consumption of animal tissues before 3.39 million years ago at Dikika, Ethiopia. Nature 2010, 466, 857. [CrossRef] [PubMed]

14. Abebe, E.A. Agricultural Marketing and Rural Incomes: Drivers and Impacts of Vertical Coordination in Food Supply Chains in Tigray, Northern Ethiopia. Ph.D. Thesis, Katholieke Universiteit Leuven, Heverlee, Belgium, 2013.

15. Tafere, K.; Worku, I. Consumption Patterns of Livestock Products in Ethiopia: Elasticity Estimates Using HICES (2004/05) Data. In Proceedings of the 9th Conference of the Ethiopian Economic Association, Addis Ababa, Ethiopia, 21-23 July 2011.

16. Swain, A. Ethiopia, the Sudan, and Egypt. J. Mod. Afr. Stud. 1997, 35, 675-694. [CrossRef]

17. McCartney, M. Decision Support Systems for Large Dam Planning and Operation in Africa, Colombo, Sri Lanka; IWMI: Colombo, Sri Lanka, 2007.

18. Desta, M.B.; Asgedom, A.G.; Gebremedhin, Y.W. Health Risk Assessment of Heavy Metals Bioaccumulation in Water, Sediment and Three Fish species (LabeobarbusSpp, ClariasGariepinus and Oreochromisniloticus) of Tekeze River Dam, Tigray, Northern Ethiopia. J. Atmos. Earth Environ. 2012, 1, 19-29.

19. Marsden, T.; Jo, B.; Gillian, B. Food Supply Chain Approaches: Exploring their Role in Rural Development. Sociol. Rural. 2000, 40, 424-438. [CrossRef]

20. Khatun, D.; Roy, B.C. Rural Livelihood Diversification in West Bengal: Determinants and Constraints. Agric. Econ. Res. Rev. 2012, 25, 115-124.

21. Ellis, F. Rural Livelihood and Diversity in Developing Countries; Oxford University Press: Oxford, UK, 2000.

22. Ellis, F. The Determinants of Rural Livelihood Diversification in Developing countries. J. Agric. Econ. 2000, 51, 289-302. [CrossRef]

23. Kula, O.; Downing, J.; Field, M. Globalization and the Small Firm: An Industry Value Chain Approach to Economic Growth and Poverty Reduction; microReport \#42; USAID: Washington, DC, USA, 2006.

24. Bolwig, S.; Stefano, P.; Andries du, T.; Lone, R.; Niels, H. Integrating Poverty and Environmental Concerns into Value-Chain Analysis: A Conceptual Framework. Dev. Policy Rev. 2010, 28, 173-194. [CrossRef]

25. Borbora, S. Financing Value Chains for Developing Rural Livelihoods. Int. J. Manag. Value Supply Chains (IJMVSC) 2014, 5, 1. [CrossRef]

26. Rosales, R.M.; Pomeroy, R.; Calabio, I.J.; Batong, M.; Cedo, K.; Escara, N.; Facunla, V.; Gulayan, A.; Narvadez, M.; Sarahadil, M.; et al. Value chain analysis and small-scale fisheries management. Mar. Policy 2017, 83, 11-21. [CrossRef]

27. Trienekens, H.J. Agricultural value chain in developing countries a framework for analysis. Int. Food Agribus. Manag. Rev. 2011, 14, 51-82.

28. Andriesse, E. Primary sector value chains, poverty reduction, and rural development challenges in the Philippines. Geogr. Rev. 2018, 108, 345-366. [CrossRef]

29. Kaplinsky, R.; Morris, M. A Handbook for Value Chains Research; IDRC-International Development Research Center: Ottawa, ON, Canada, 2003; Available online: http:/ / www.value-chains.org (accessed on 13 May 2015).

30. Saarelainen, E.; Sievers, M. Combining Value Chain Development: Value Chain Development; ILO Value Chain Development Briefing Paper 1; ILO: Geneva, Switzerland, 2011.

31. Gebremedhin, B.; Jaleta, M.; Hoekstra, D. Smallholders, institutional services and commercial transformation in Ethiopia. Agric. Econ. 2009, 40, 773-787. [CrossRef]

32. Israel, G.D. Determining Sample Size, Agricultural Education and Communication Department; PEOD6 (Reviewed 2013); University of Florida, IFAS Extension: Gainesville, FL, USA, 1992.

33. Imbens, G. Nonparametric estimation of average treatment effects under exogeneity: A review. Rev. Econ. Stat. 2004, 96, 4-29. [CrossRef]

34. Ito, J.; Bao, Z.; Su, Q. Distributional effects of agricultural cooperatives in China: Exclusion of smallholders and potential gains on participation. Food Policy 2012, 37, 700-709. [CrossRef]

35. Jena, P.R.; Chichaibelu, B.B.; Stellmacher, T.; Grote, U. The Impact of coffee certification on smallholder producers' livelihoods: A case study from the Jimma zone, Ethiopia. Agric. Econ. 2012, 43, 329-440. [CrossRef]

36. Abebaw, D.; Haile, G.M. The impact of cooperatives on agricultural technology adoption: Empirical evidence from Ethiopia. Food Policy 2013, 38, 82-91. [CrossRef] 
37. Khandker, R.; Gayatri, B.; Hussain, A. Handbook on Impact Evaluation: Quantitative Methods and Practices; The World Bank: Washington, DC, USA, 2010.

38. Imbens, G.; Angrist, J. Two-stage least square estimation of average causal effects in models with variable treatment intensity. J. Am. Stat. Assoc. 1995, 90, 431-442.

39. Rosenbaum, P.R.; Rubin, D.B. The central role of propensity score in observational studies for causal effects. Biometrika 1983, 70, 41-55. [CrossRef]

40. Dehejia, R.H.; Wahba, S. Propensity score-matching methods for non-experimental causal studies. Rev. Econ. Stat. 2002, 84, 151-161. [CrossRef]

41. Ichino, A.; Mealli, F.; Nannicini, T. From temporary help jobs to permanent employment: What can we learn from matching estimators and their sensitivity? J. Appl. Econ. 2008, 23, 305-327. [CrossRef]

42. Asiedu, B. An Investigation of Fish Catch and Poverty Levels for Enhanced Management of Small-Scale Fisheries of Ghana. Ph.D. Thesis, University of Ghana, Legon, Ghana, 2012.

43. Altenburg, T. Donor Approaches to Supporting Pro-Poor Value Chains. In Report Prepared for the Donor Committee for Enterprise Development_-Working Group on Linkages and Value Chains; German Development Institute (DIE): Bonn, Germany, 2007; Available online: www.value-chains.org/dyn/bds/docs/568/ DonorApproachestoPro-PoorValueChains.pdf (accessed on 24 January 2012).

44. Fowler, B.; Brand, M. Pathways Out of Poverty: Applying Key Principles of the Value Chain Approach to Reach the Very Poor; Discussion Paper/Microreport\#173; USAID: Washington, DC, USA, 2011.

45. De Silva, D.A.M.; Yamao, M. The involvement of female labor in sea food processing in Sri Lanka: Impact of organizational fairness and supervisor evaluation on employee commitment. In Proceedings of the Seventh Asian Fisheries Forum, Penang, Malaysia, 1-2 December 2004.

(C) 2018 by the authors. Licensee MDPI, Basel, Switzerland. This article is an open access article distributed under the terms and conditions of the Creative Commons Attribution (CC BY) license (http:/ / creativecommons.org/licenses/by/4.0/). 